\title{
The Evolutionary History of Beet necrotic yellow vein virus Deduced from Genetic Variation, Geographical Origin and Spread, and the Breaking of Host Resistance
}

\author{
Soutaro Chiba, ${ }^{1}$ Hideki Kondo, ${ }^{1}$ Masaki Miyanishi, ${ }^{1}$ Ida Bagus Andika, ${ }^{1}$ Chenggui Han, ${ }^{2}$ and \\ Tetsuo Tamada ${ }^{1}$ \\ ${ }^{1}$ Institute of Plant Science and Bioresources, Okayama University, Kurashiki, Okayama, 710-0046, Japan; ${ }^{2}$ State Key \\ Laboratory of Agro-Biotechnology, College of Biological Sciences, China Agricultural University, Beijing 100193, China
}

Submitted 19 October 2010. Accepted 20 October 2010.

Beet necrotic yellow vein virus (BNYVV) is an economically important pathogen of sugar beet and has been found worldwide, probably as the result of recent worldwide spread. The BNYVV genome consists of four or five RNA components. Here, we report analysis of sequence variation in the RNA3-p25, RNA4-p31, RNA2-CP, and RNA5-p26 genes of 73 worldwide isolates. The RNA3-p25 gene encodes virulence and avirulence factors. These four sets of gene sequences each fell into two to four groups, of which the three groups of $p 25$ formed eight subgroups with different geographical distributions. Each of these subgroup isolates (strains) could have arisen from four original BNYVV population and their mixed infections. The genetic diversity for BNYVV was relatively small. Selection pressure varied greatly depending on the BNYVV gene and geographical location. Isolates of the Italy strain, in which $p 25$ was subject to the strongest positive selection, were able to overcome the $R z 1$-host resistance gene to differing degrees, whereas other geographically limited strains could not. Resistance-breaking variants were generated by $\mathrm{p} 25$ amino acid changes at positions 67 and 68 . Our studies suggest that BNYVV originally evolved in East Asia and has recently become a pathogen of cultivated sugar beet followed by the emergence of new resistance-breaking variants.

\section{S. Chiba and H. Kondo contributed equally to this work.}

Current address for T. Tamada: Kita 10, Nishi 1, 13-2-606, Sapporo, 0010010, Japan.

Current address for M. Miyanishi: Sigma Aldrich Japan K. K. Custom Products Operations Ishikari, Hokkaido, 061-3241, Japan.

Current address for I. B. Andika: Zhejiang Academy of Agricultural Sciences, Hangzhou 310021, China.

Corresponding author: T. Tamada; E-mail: tyrotamada@oboe.ocn.ne.jp

Nucleotide sequence data is available in the GenBank/EMBL/DDBJ databases under accession numbers AB562977 to AB563030 (BNYVV CP sequences), AB563031 to AB563092 (p25 sequences), AB563093 to AB563143 (p31 sequences), and AB563144 to AB563152 (p26 sequences).

* The $\boldsymbol{e}$-Xtra logo stands for "electronic extra" and indicates that four supplementary tables and one supplementary figure are published online. Also Figures 1, 2, and 3 appear in color online.
Studies on the genetic variability of viruses provide information that can clarify their evolutionary and geographical origins, virulence changes (resistance-breaking) (RB), and the development of new epidemics. In plant viruses, genomic variation caused by mutation is enhanced by recombination, reassortment, and acquisition of extra genomic components. Genomic RNA typically has a high mutation rate, and individual virus isolates consist of a swarm of very closely related mutants, with the consensus sequence able to change in response to selection pressure (Garcia-Arenal et al. 2001; Harrison 2002). Plant viruses infrequently break host plant resistances, despite having high mutation rates and short replication cycles and producing large populations within individual host plants. In some viruses, major viral gene-encoded proteins, such as coat protein $(\mathrm{CP})$, RNA polymerase, movement proteins, or proteases, are known to function as avirulence factors that elicit resistance controlled by cognate dominant host genes (Harrison 2002).

In contrast to other well-studied plant viruses, Beet necrotic yellow vein virus (BNYVV), which has four or five genomic messenger-like RNA species, is unique in generating RB variants through mutations in a gene that is located in a genomic RNA. The essential genomic components RNA1 and RNA2 together control RNA replication, assembly, and cell-to-cell movement. Extra genomic components consist of the smaller RNA3, RNA4, and RNA5, each of which plays an important but different role in pathogenicity and vector transmission (Richards and Tamada 1992; Tamada 1999). We have particularly studied the existence and function of these extra genomic components. Thus, the RNA3-encoded $25-\mathrm{kDa}$ protein (p25) controls disease symptoms in sugar beet roots (Tamada et al. 1999). The p 25 protein also functions as an avirulence factor in leaves of some resistant sugar beet lines, and this interaction is controlled by single amino acid changes in p25 (Chiba et al. 2008). The RNA4-encoded 31-kDa protein (p31) is involved in efficient vector transmission and in root-specific silencing suppression (Rahim et al. 2007), whereas the RNA5-encoded 26$\mathrm{kDa}$ protein (p26) is associated with symptom severity but is dispensable for BNYVV survival (Tamada et al. 1989).

BNYVV is the causal agent of rhizomania disease of sugar beet. Its vector is the soilborne plasmodiophorid Polymyxa betae (Richards and Tamada 1992). First reported in Italy in the early 1950s (Canova 1959), BNYVV spread from central and southern Europe to eastern and northern Europe and the Middle East within a few decades (Asher 1993; McGrann et al. 
2009; Tamada 1999). BNYVV was found in the United Kingdom and Spain in the late 1980s and in Scandinavian countries in the late 1990s. It was first found in Japan in 1965, in China in 1978, and in the United States in 1983. Thus, rhizomania is now one of the most cosmopolitan and economically important sugar beet diseases. Sugar beet production has become dependent on resistant sugar beet cultivars to control the disease. Screening tests for such resistance started in northern Italy in the mid-1960s (Biancardi et al. 2002). The first cultivar (Rizor) with a high level of resistance was introduced in 1985 and grown in infested parts of several European countries in the early 1990s (Asher 1993). Subsequently, sugar beet possessing the Holly resistance source (gene $R z 1$ ), which confers much higher levels of resistance to BNYVV, has been incorporated in many current cultivars (Asher 1993; Lewellen et al. 1987; Rush 2003). In addition to the $R z l$ gene, cultivars possessing other resistance genes, such as $R_{z} 2, R_{z} 3, R_{z} 4$, and $R_{z} 5$, have been produced (Grimmer et al. 2007; McGrann et al. 2009; Scholten and Lange 2000).

Recently, however, severe symptoms have been found in cultivars carrying the $R z 1$ gene in some areas of the United States and Europe, indicating the emergence of $\mathrm{RB}$ virus strains (Liu and Lewellen 2007; Liu et al. 2005). Schirmer and associates (2005) analyzed the $C P$ and $p 25$ gene sequences of BNYVV isolates collected worldwide and found that the $C P$ gene was highly conserved, whereas the p25 gene was more variable, with evidence of strong positive selection of amino acid residues 67 to 70 , and suggested its association with RB. Indeed, amino acid 68 in p25 was demonstrated to control certain virus-host-specific resistance interactions (Chiba et al. 2008). Furthermore, Acosta-Leal and associates (2008) reported positive selection of amino acids 67 and 68 in RB isolates in the United States; isolates with valine at position 67 induced more severe symptoms in resistant cultivars than a wild-type isolate with alanine at that position (Acosta-Leal et al. 2008, 2010; Koenig et al. 2009; Pferdmenges et al. 2009). In addition, residues 67 to 70 were not the only amino acids in $p 25$ linked to RB (Acosta-Leal and Rush 2007; Chiba et al. 2008; Liu and Lewellen 2007).

From studies on their $C P$ genes, BNYVV isolates were classified into two groups, A and B (Kruse et al. 1994; Saito et al. 1996; Schirmer et al. 2005). A further group, P-type, that contained an RNA5 molecule was isolated from the Pithiviers area of France (Koenig et al. 1997) but was closely related to the Atype (Miyanishi et al. 1999). A-type BNYVV is distributed worldwide (Schirmer et al. 2005) whereas the B-type virus occurs in limited areas of Europe (Koenig et al. 2008), although isolates with B-type $C P$ were also found in Japan (Miyanishi et al. 1999) and China (Li et al. 2008). RNA5-containing viruses occur in small limited areas of France (Schirmer et al. 2005), Germany (Koenig et al. 2008), and the United Kingdom (Ward et al. 2007) but are widely distributed in Asia (Koenig and Lennefors 2000; Li et al. 2008; Miyanishi et al. 1999). Isolates with the P-type $p 25$ gene but without RNA5 occur in the United States (Liu and Lewellen 2007) and Iran (Mehrvar et al. 2009). Thus, geographical distribution of BNYVV variants is complicated and the evolutionary relationships among variants remain unknown.

In this study, we first sequenced the $p 25$ gene in 65 BNYVV isolates collected from all over the world and then the $p 31, C P$, and $p 26$ genes of selected isolates. These data were analyzed together with those for eight isolates published previously. Subsequently, the virulence of representative isolates was examined by foliar rub inoculation and by vector inoculation of indicator plants. We analyzed our data to obtain information on the global biogeography, evolution, virulence, and spread of BNYVV.

\section{RESULTS}

\section{BNYVV isolates used}

to access the genetic variability of BNYVV.

Schirmer and associates (2005) analyzed the $C P$ (RNA2), p25 (RNA3), and p26 (RNA5) gene sequences of 136 BNYVV isolates collected worldwide, and showed that the $C P$ and $p 25$ sequences could be divided roughly into two and three groups, respectively, and assigned some sequences of Japanese and Chinese isolates to subgroups. To obtain further information on the genetic variability of BNYVV isolates, in this study, we examined the variation of the $C P, p 25, p 31$ (RNA4), and $p 26$ gene sequences of 65 BNYVV isolates collected from East Asia (Japan and China), Europe (Italy, France, Germany, Slovakia, Hungary, and Spain), the Middle East (Turkey), and the United States, most of which were collected in 1991 to 2000 (Supplementary Table S1). All BNYVV isolates used in this study were derived from soil samples collected from fields with rhizomania disease. Each BNYVV isolate that had been isolated from a soil using bait plants was propagated in inoculated leaves of Tetragonia expansa (Tamada et al. 1989) and its genome was sequenced. Thus, it should be noted that the sequence we determined had been selected from natural populations and, therefore, might not represent the complete viral population in the infested field. We first tested for RNA5 and sequenced the $p 25$ gene of all isolates, and then sequenced the $p 31, C P$, and $p 26$ genes of selected isolates. The resulting data were analyzed together with the corresponding genome sequences published for eight isolates: Kas2 and Kas3 from Kazakhstan (Koenig and Lennefors 2000; Ward et al. 2007), UK$\mathrm{MH}$ and UK-FF from the United Kingdom (Ward et al. 2007), Bao and Har4 from China (Li et al. 2008), OW1 from Germany (Koenig et al. 2008), and IR-GR1 from Iran (Mehrvar et al. 2009).

\section{Phylogenetic and phylogeographical profiles of BNYVV isolates.}

Preliminary phylogenetic analyses of the three gene sequences $(C P, p 25$, and $p 31)$ indicated that some of the isolates might be reassortants or recombinants, because they occurred in different positions in the separate trees inferred from the sequences of different genes. To clarify the phylogenetic relationships of the isolates, it was necessary to identify isolates with multiple parents. This was done by joining the three gene sequences $(C P, p 25$, and $p 31)$ for each of the 52 BNYVV isolates to produce single long "concatenates" (Ohshima et al. 2002; Schirmer et al. 2005). The concatenates were then aligned using MAFFT 6 , and the alignments were analyzed using RDP3. The six isolates $(\mathrm{CH} 2, \mathrm{CH} 3, \mathrm{CH} 5, \mathrm{CH} 7, \mathrm{~S} 12$, and S42) were found to be reassortants because they gave clear "recombination" signals at one or both gene boundaries of the concatenates. RDP3 also gave no clear evidence of true recombination within the genes.

The 43 concatenates remaining after the nine reassortants containing the anomalous sequences had been removed were analyzed using PhyML 3.0 in the presence or absence of the corresponding sequences of Beet soil-borne mosaic virus (BSBMV), which was included because BSBMV is the nearest BNYVV relative with published sequences of the genes we were studying. These comparisons showed that BSBMV was not closely enough related to BNYVV to be a reliable outgroup; the patristic distances between the BSBMV gene and those in the BNYVV cluster were more than 40 times greater than the distances within the BNYVV cluster and, with distances of 3.3 substitutions/site or more between BSBMV and BNYVV genes, they were outside the limit of reliability of maximum likelihood (ML) estimates (Schwartz and Mueller 2010). 


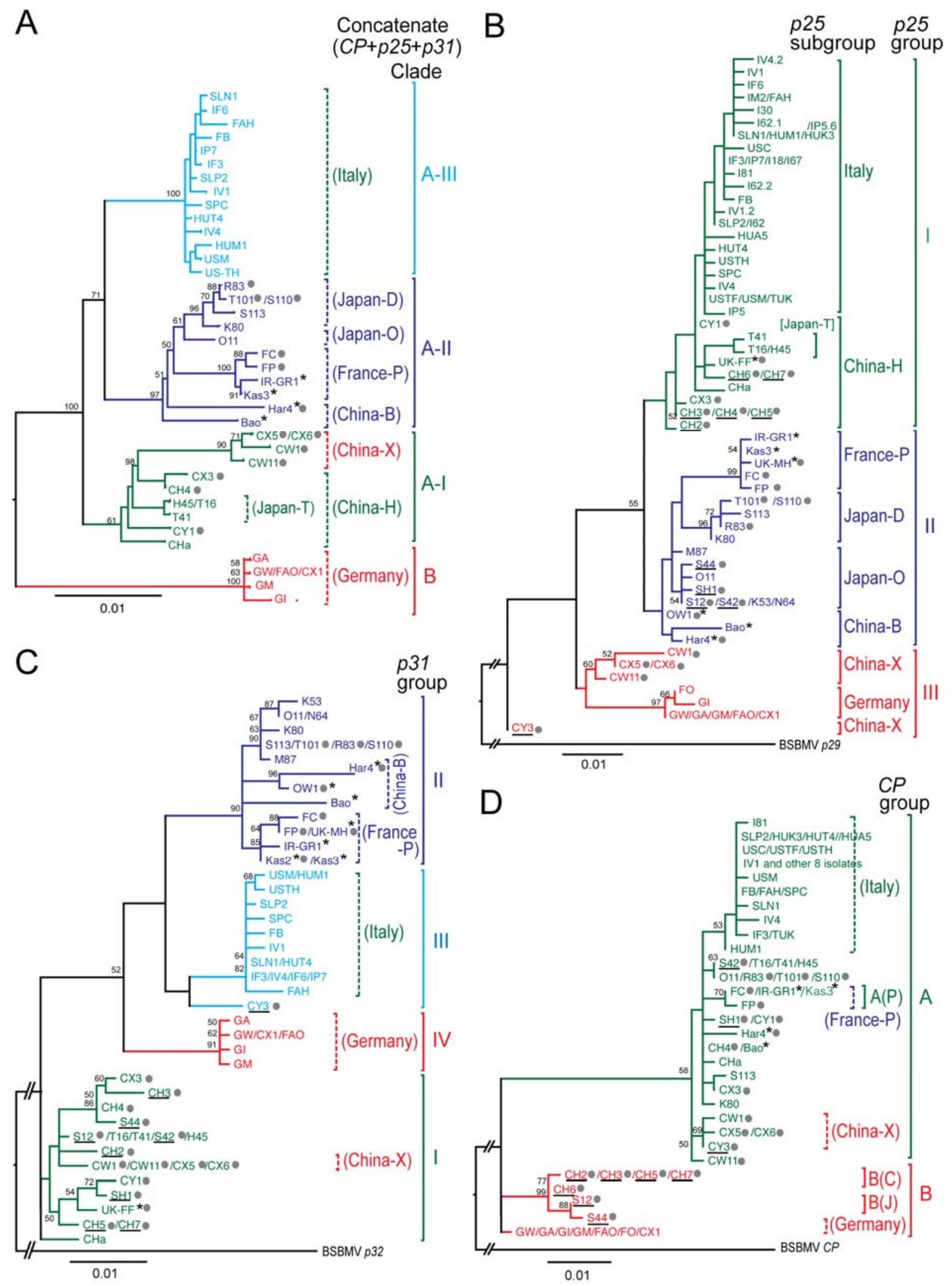

Fig. 1. Phylogenetic trees of 73 isolates of Beet necrotic yellow vein virus calculated from the concatenated sequences of A, three genes; B, RNA3-p25 gene; C, RNA4-p31 gene; and D, RNA2-CP gene. The trees were constructed by the maximum likelihood (ML) method using PhyML 3.0. The ML bootstrap support of the nodes is indicated as percentages from 100 replicates (only values $>50 \%$ are shown). For analyses of individual genes (B, C, and D), Beet soilborne mosaic virus was used as the outgroup (BSBMV accession numbers CP:AAC18568, p29:AAF91436, and p32:ACJ60504). The asterisks indicate sequences reported by other laboratories (Koenig and Lennefors 2000; Koenig et al. 2008; Li et al. 2008; Mehrvare et al. 2009; Ward et al. 2007). The gray circles indicate isolates containing RNA5. Reassortant isolates are underlined. Clades of concatenates, groups of individual genes, and subgroups of the $p 25$ gene are indicated by vertical solid bars to the right of the figures. Corresponding $p 25$ subgroups (in parentheses) are indicated by vertical dotted bars in parts $\mathrm{A}, \mathrm{C}$, and D. 
The midpoint-rooted tree calculated from nonreassortants (Fig. 1A) divided most of the BNYVV isolates into four distinct lineages (clades). Trees calculated from the sequences of the three individual genes were broadly similar to the concatenate tree (Fig. 1B, C, and D) but emphasized different components of it; note that the individual gene trees included the sequences from the reassortant isolates, the names of which are underlined.

The p25 tree (Fig. 1B) was calculated from sequences from 73 isolates. Its topology is closest to that of the concatenate tree, and it has three main lineages (groups I, II, and III) that divide into subgroups, each of which was of isolates from a single geographical region. Therefore, we named the subgroups after the country in which the first isolate of the subgroup was found. The $p 31$ tree (Fig. 1C) was calculated from the sequences of 59 isolates, and these fell into four groups (I, II, III, and IV), which corresponded, with a few exceptions, to the four clades of the concatenate tree. The $C P$ tree (Fig. 1D) was of sequences from 66 isolates. It had two groups, a large group A and a small group B that contained many reassortant isolates. The $p 26$ tree (Supplementary Fig. S1) was of sequences from 37 isolates, including data published previously (Kiguchi et al. 1996; Miyanishi et al. 1999). The $p 26$ gene, which is in RNA5, was found in most isolates except the Italy and Germany subgroups (Fig. 1A and B). Its sequences fell into three groups (I, II, and III), one of which contained the France-P isolates and another only two Japan-O isolates (Miyanishi et al. 1999).

\section{Geographical distribution and spread of BNYVV isolate groups.}

The phylogenetic analyses of individual genes and the concatenate sequences indicate that there are eight clusters of iso-

Table 1. Nucleotide diversity of four genes of Beet necrotic yellow vein virus isolates ${ }^{\mathrm{a}}$

\begin{tabular}{|c|c|c|c|c|}
\hline Gene, group $^{b}$ & $D^{\mathbf{c}}$ & $d_{N S}$ & $d_{S}$ & $d_{N S} / d_{S}$ \\
\hline \multicolumn{5}{|l|}{$C P$} \\
\hline Group A & $0.007(0.002)$ & 0.001 & 0.021 & 0.048 \\
\hline (Italy p25 sub.) & $0.002(0.001)$ & 0.002 & 0.006 & 0.333 \\
\hline Group B & $0.007(0.002)$ & 0.004 & 0.016 & 0.250 \\
\hline All isolates & $0.017(0.003)$ & 0.004 & 0.045 & 0.089 \\
\hline \multicolumn{5}{|l|}{ p25 } \\
\hline Group I & $0.007(0.002)$ & 0.007 & 0.006 & 1.167 \\
\hline (Italy p25 sub.) & $0.005(0.001)$ & 0.006 & 0.004 & 1.500 \\
\hline Group II & $0.012(0.003)$ & 0.012 & 0.013 & 0.923 \\
\hline Group III & $0.018(0.004)$ & 0.013 & 0.030 & 0.433 \\
\hline All isolates & $0.016(0.003)$ & 0.014 & 0.018 & 0.778 \\
\hline \multicolumn{5}{|l|}{ p31 } \\
\hline Group I & $0.010(0.002)$ & 0.003 & 0.030 & 0.100 \\
\hline Group II & $0.011(0.002)$ & 0.004 & 0.029 & 0.138 \\
\hline Group III & $0.006(0.001)$ & 0.004 & 0.009 & 0.444 \\
\hline (Italy p25 sub.) & $0.004(0.001)$ & 0.003 & 0.006 & 0.500 \\
\hline Group IV & $0.002(0.001)$ & 0.001 & 0.011 & 0.091 \\
\hline All isolates & $0.025(0.003)$ & 0.016 & 0.049 & 0.327 \\
\hline \multicolumn{5}{|l|}{$p 26$} \\
\hline Group I & $0.010(0.002)$ & 0.007 & 0.017 & 0.412 \\
\hline Group II & $0.018(0.004)$ & 0.015 & 0.021 & 0.714 \\
\hline Group III & $0.004(0.003)$ & 0.002 & 0.009 & 0.222 \\
\hline All isolates & $0.019(0.003)$ & 0.013 & 0.030 & 0.433 \\
\hline
\end{tabular}

a Substitutions: $d_{N S}=$ average number of nonsynonymous substitutions per nonsynonymous site, $d_{S}=$ average number of synonymous substitutions per synonymous site, and $d_{N S} / d_{S}=$ average of the ratio between nonsynonymous and synonymous substitutions.

${ }^{\mathrm{b}}$ For the Italy $p 25$ subgroup in parentheses, numeric values of only Italy p25 subgroup isolates drawn from the respective coat protein $(C P)$ group A, $p 25$ group I, and $p 31$ group III.

${ }^{\mathrm{c}} D=$ nucleotide diversity: average number of nucleotide substitutions per site between all pairs of sequences in the group. Standard errors are indicated in parentheses. lates. These clusters are seen most clearly in the concatenate and p25 phylogenies (Fig. 1A and B), and they correlate best with the history of isolation and the geography and spread of the isolates. i) Italy isolates (Fig. 1A, clade A-III; Fig. 1B, p25 group I), the largest cluster, were first found in Italy in the 1950s, and now also include isolates from France, Hungary, Slovakia, Turkey, Spain, and the United States as well as those from Italy. Other Italy isolates have subsequently been reported from other European countries (Koenig and Lennefors 2000; Koenig et al. 2008; Schirmer et al. 2005) and the Middle East (Mehrvar et al. 2009); thus, the Italy strain is now known to be widely distributed throughout the world but not East Asia. ii) Germany isolates (clade B, p25 group III) were first found in Germany and France in the early 1970s and later in Belgium, Austria, Switzerland, and Czech Republic (Koenig and Lennefors 2000; Koenig et al. 2008; Schirmer et al. 2005). A Chinese isolate (CX1) in Xinjiang province is clearly a German strain isolate. iii) Japan-O (Obihiro) isolates (clade A-II, p25 group II) were first found in the 1960s and widely distributed in central and eastern Hokkaido. iv) China-B (Bautou) isolates (Bao and Har4) (clade A-II, p25 group II) were found in China (Li et al. 2008), and a German isolate, OW1 (Koenig et al. 2008), is also a China-B strain isolate. v) Japan-D (Date) isolates (clade A-II, p25 group II) are all from southern areas of Hokkaido since the 1960s. vi) France-P (Pithiviers) isolates (clade A-II, p25 group II) were first found in small areas of France in the 1970s but then also in Kazakhstan (Koenig and Lennefors 2000) and, more recently, in the United Kingdom (UK-MH) (Ward et al. 2007) and Iran (IR-GR1) (Mehrvar et al. 2009). The U.S. isolates IV7 and IV8 had the same SYHG tetrad sequence (residues 67 to 70 ) as France-P p25 (Liu and Lewellen 2007) but no information on their other genes has been reported. vii) China-H (Hohhot) isolates (clade A-I, p25 group I) were found in Nei Menggu, Ningxia Huizu, Xingjiang, and Heilongjiang provinces. Japanese isolates of this cluster, called Japan-T (Tsubetsu), were first found in small areas of east Hokkaido in the 1960s. The UK-FF isolate recently found in the United Kingdom (Ward et al. 2007) is also a China-H isolate. viii) China-X (Xingjiang) isolates (clade A-I, p25 group III) have only been found at Ningxia Huizu, Gansu, and Xinjiang provinces.

\section{Dependence of selection pressure on BNYVV gene and geographical source.}

Estimates of the genetic diversity of the four BNYVV genes gave additional information about their phylogenetic history and the structure of BNYVV populations. The mean nucleotide diversities for the $C P, p 25, p 31$, and $p 26$ genes were $0.017,0.016,0.025$, and 0.019 , respectively (Table 1 ). These are smaller values than many of those reported for other plant viruses (Garcia-Arenal et al. 2001), suggesting that BNYVV populations are genetically very stable or have arisen relatively recently. The within-group diversity of BNYVV genes was even less, ranging from 0.002 to 0.018 (Table 1). These results suggest that, although the population sizes differ between groups, the rates of evolution of the four genes may be similar.

To assess the selection pressure on individual codons in each BNYVV protein, we next estimated pairwise synonymous nucleotide substitutions per synonymous site $\left(d_{S}\right)$ and nonsynonymous substitutions per nonsynonymous site $\left(d_{N S}\right)$ using the Pamilo-Bianchi-Li (PBL) method. When all isolates were included, the $d_{N S} / d_{S}$ ratio for $C P$ was 0.089 (Table 1 ). This value resembles that for $\mathrm{CP}$ of other plant RNA viruses, and is taken as evidence that they are under negative (purifying) selection (Chare and Holmes 2004; Garcia-Arenal et al. 2001). In contrast, the $d_{N S} / d_{S}$ ratio for the $p 25$ gene was much greater (0.778), whereas those for $p 31$ and $p 26$ were intermediate 
(0.327 and 0.433 , respectively) (Table 1$)$. Most interestingly, however, the $d_{N S} / d_{S}$ ratios differed greatly for different $p 25$ groups: $1.167,0.923$, and 0.433 for groups I, II, and III, respectively. This indicates that the group I p25 is probably under positive selection and the group III $p 25$ under negative selection. Similarly, the value of the $d_{N S} / d_{S}$ ratio for group III p31 gene was considerably greater than that for groups I, II, and IV (Table 1). Also, the $d_{N S} / d_{S}$ value for B group $C P$ was five times greater than that for A group $C P(0.048)$, though few samples were involved. Thus, the selection pressure on BNYVV proteins varied, depending on the gene and the isolate group, suggesting that different selection pressures might operate in different geographical regions or during the movement to new regions.

\section{Amino acid differences in three gene proteins.}

Major amino acid differences were found in p25 (Table 2). For the Italy isolates, the amino acids (F, Y, C, H, L, or Q) occurred in different isolates at position 68. One Spain isolate (SPC) had a change from $\mathrm{A}$ to $\mathrm{V}$ at position 67. For some Italy isolates (more than five clones per isolate were sequenced), multiple replacements at position 68 were detected in isolates from one original source. For example, the I62 isolate gave p25 proteins with either $\mathrm{F}, \mathrm{H}$, or $\mathrm{L}$ at position 68 and, likewise, the IV4 and IP5 isolates had C or H and the IV1 isolate Q or F at the same site (Fig. 1B). We also noticed that p25 variants containing amino acid residues $\mathrm{H}$ or $\mathrm{L}$ or $\mathrm{C}$ were very common in Italy strain isolates (Table 2). However, differences occurred, although less frequently, at other sites.

Similar, although usually smaller, differences were found scattered throughout the p31 sequences (Supplementary Table S2) but there was no obvious link with reassortants. In all, 7 to 14 amino acid changes were found between the groups, whereas no or a few amino acid substitutions were found within the group, with a few exceptions. Likewise, the differences between CP A and B groups were at only few sites (Supplementary Table S3). Furthermore, there were one or two amino acid differences in the $C P$ gene among geographical different isolates in either A or B group (Fig. 1D); for example, among B group $\mathrm{CP}(\mathrm{B})$, Chinese $\mathrm{B}$ group $\mathrm{CP}(\mathrm{B}-(\mathrm{C}))$, and Japanese B group $C P(B(J))$, or between A group $C P(A)$ and French-P group $\mathrm{CP}(\mathrm{A}(\mathrm{P}))$.

\section{Virulence of BNYVV isolates assessed \\ by foliar rub inoculation.}

Our previous studies showed that resistance and susceptibility to BNYVV can be assessed, at least partially, by the response of test plants to foliar rub inoculation (Tamada 2007), and also that the resistance phenotype (avirulence) correlated with specific amino acid differences in p 25 (Chiba et al. 2008), especially residue 68 . The response to 20 representative BNYVV isolates, including 8 isolates studied previously (Chiba et al. 2008), of wild beet plant Beta vulgaris subsp. maritima lines MR0, MR1, and MR2 is shown in Table 3. The isolates O11, SH1, S12, and SLP2, all of which had p25 with F68, were avirulent in MR1 and MR2 plants. Five isolates (S113, T101, HUA5, FP, and CH6) with Y68 were avirulent in MR2 plants, whereas MR1 plants were susceptible, and the MR0, MR1, and MR2 lines were all susceptible to isolates T41, GW, and CY3. These differences correlated with amino acid differences ( $\mathrm{N}$ or $\mathrm{D}$ ) at position 179 (Table 3). In addition, both MR1 and MR2 were susceptible to BNYVV isolates containing p25 with $\mathrm{C}$ or $\mathrm{H}$ or $\mathrm{L}$ or $\mathrm{Q}$ at position 68 (Table 3). These results confirm our previous report (Chiba et al. 2008), which showed that the p25 amino acids at positions 68 and 179 , regardless of the grouping of $p 25, p 31$, and $C P$, are associated with avirulence of BNYVV in leaves of the wild beet indicator plants.

\section{Virulence of BNYVV isolates assessed by root inoculation by the vector.}

In all, 18 of the 20 BNYVV isolates used for foliar rub inoculation were selected and used to test the response of different sugar beet cultivars to root inoculation with BNYVV by $P$. betae (Table 3). We found that, when the original soil source of BNYVV-carrying $P$. betae was used to inoculate sugar beet

Table 2. Major amino acid differences in the RNA3-encoded p25 protein (p25) of Beet necrotic yellow vein virus (BNYVV) isolates

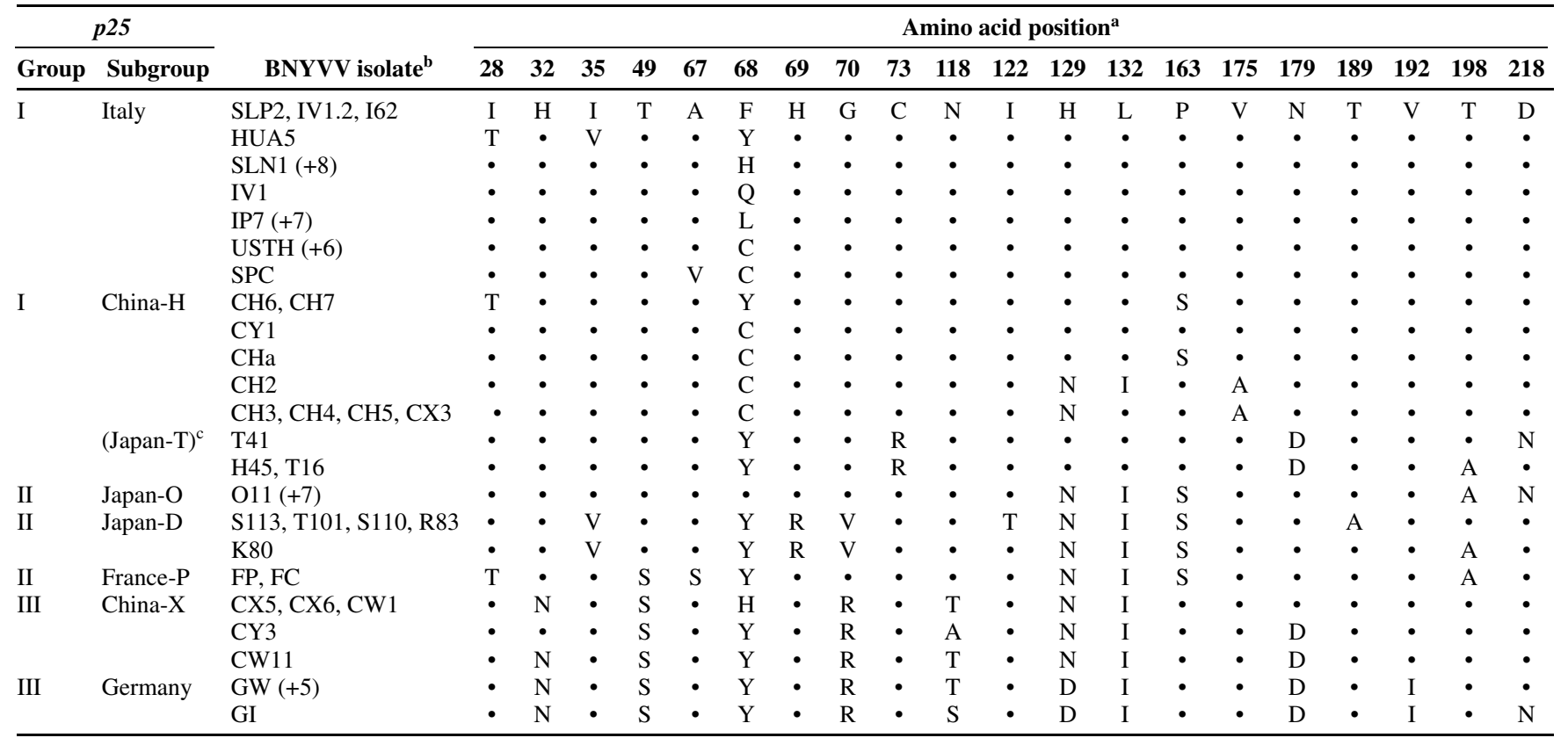

\footnotetext{
${ }^{a}$ Amino acid changes that appeared to be minor were excluded. Dots indicate amino acid residues identical to p25 from BNYVV isolate SLP2.

${ }^{\mathrm{b}}$ Plus-signed numbers in parentheses indicate the numbers of isolates (including $p 25$ variants in mixed infections) that contain the same amino acid residues at indicated positions.

c Japan-T (in parenthesis) is included in China-H subgroup.
} 
roots, root symptoms were frequently obscured by simultaneous infection with various soil microorganisms, including saprophytic fungi, bacteria, and soilborne viruses other than BNYVV. To eliminate this problem, a virus-free $P$. betae culture was allowed to acquire BNYVV from virus-infected $B$. macrocarpa roots. The viruliferous $P$. betae cultures carrying each BNYVV isolate were used to inoculate the roots of seedlings of a susceptible sugar beet cultivar (Monomidori) and Rzl-resistant sugar beet cultivar (Schwert). After 3 to 4 weeks in growth cabinets, no differences were found in the virus content of rootlets inocu- lated with different BNYVV isolates or rootlets of different sugar beet cultivars (data not shown). The virus-infected seedlings were then moved to a greenhouse. Symptom severity was assessed after 2 to 3 months using a visual scale (Fig. 2). In the susceptible cv. Monomidori, all 11 RNA5-lacking isolates induced similar severe symptoms, whereas the 7 RNA5-containing isolates produced very severe symptoms, with slight differences between isolates (Table 3). In contrast, the resistant cv. Schwert showed different levels of symptom severity, depending on the virus isolate. Six isolates (O11, S113, T41, SLP2, HUA5,

Table 3. Virulence of representative Beet necrotic yellow vein virus isolates assessed by foliar rub inoculation to wild beet plants and root vector inoculation to sugar beet cultivars ${ }^{\mathrm{a}}$

\begin{tabular}{|c|c|c|c|c|c|c|c|c|c|c|c|c|c|c|c|}
\hline \multirow[b]{2}{*}{ Isolate } & \multicolumn{4}{|c|}{ Group } & \multirow{2}{*}{$\frac{\text { Subgroup }^{\mathrm{b}}}{P 25}$} & \multicolumn{5}{|c|}{ p25 position } & \multicolumn{3}{|c|}{ Foliar rub inoculation ${ }^{c}$} & \multicolumn{2}{|c|}{$\begin{array}{l}\text { Vector root } \\
\text { inoculation }^{d}\end{array}$} \\
\hline & $p 26$ & $C P$ & p31 & $p 25$ & & 67 & 68 & 69 & 70 & 179 & MR0 & MR1 & MR2 & Mono & Schw \\
\hline O11 & - & A & II & II & Japan-O & A & $\mathrm{F}$ & $\mathrm{H}$ & $\mathrm{G}$ & $\mathrm{N}$ & $\mathrm{S}$ & $\mathrm{R}$ & $\mathrm{R}$ & 3 & 0 \\
\hline S113 & - & A & II & II & Japan-D & A & $\mathrm{Y}$ & $\mathrm{R}$ & V & $\mathrm{N}$ & $\mathrm{S}$ & $\mathrm{S}$ & $\mathrm{R}$ & 3 & 0 \\
\hline T41 & - & A & I & I & (Japan-T) & $\mathrm{A}$ & $\mathrm{Y}$ & $\mathrm{H}$ & $\mathrm{G}$ & $\mathrm{D}$ & $\mathrm{S}$ & $\mathrm{S}$ & $\mathrm{S}$ & 3 & 0 \\
\hline SLP2 & - & A & III & I & Italy & A & $\mathrm{F}$ & $\mathrm{H}$ & $\mathrm{G}$ & $\mathrm{N}$ & $\mathrm{S}$ & $\mathrm{R}$ & $\mathrm{R}$ & 3 & 0 \\
\hline HUA5 & - & A & III & I & Italy & A & $\mathrm{Y}$ & $\mathrm{H}$ & $\mathrm{G}$ & $\mathrm{N}$ & $\mathrm{S}$ & $\mathrm{S}$ & $\mathrm{R}$ & 3 & 0 \\
\hline SLN1 & - & A & III & I & Italy & A & $\mathrm{H}$ & $\mathrm{H}$ & $\mathrm{G}$ & $\mathrm{N}$ & $\mathrm{S}$ & $\mathrm{S}$ & $\mathrm{S}$ & 3 & 1 \\
\hline IP7 & - & A & III & I & Italy & $\mathrm{A}$ & $\mathrm{L}$ & $\mathrm{H}$ & $\mathrm{G}$ & $\mathrm{N}$ & $\mathrm{S}$ & $\mathrm{S}$ & $\mathrm{S}$ & 3 & 1 \\
\hline IV1 & - & A & III & I & Italy & A & Q & $\mathrm{H}$ & $\mathrm{G}$ & $\mathrm{N}$ & $\mathrm{S}$ & $\mathrm{S}$ & $\mathrm{S}$ & 3 & $1-2$ \\
\hline USTH & - & A & III & I & Italy & A & $\mathrm{C}$ & $\mathrm{H}$ & $\mathrm{G}$ & $\mathrm{N}$ & $\mathrm{S}$ & $\mathrm{S}$ & $\mathrm{S}$ & 3 & 1 \\
\hline SPC & - & A & III & I & Italy & $\mathrm{V}$ & $\mathrm{C}$ & $\mathrm{H}$ & $\mathrm{G}$ & $\mathrm{N}$ & $\mathrm{S}$ & $\mathrm{S}$ & $\mathrm{S}$ & 3 & 2 \\
\hline GW & - & B & IV & III & Germany & A & $\mathrm{Y}$ & $\mathrm{H}$ & $\mathrm{R}$ & $\mathrm{D}$ & $\mathrm{S}$ & $\mathrm{S}$ & $\mathrm{S}$ & 3 & 0 \\
\hline SH1 & I & A & I & II & Japan-O & A & $\mathrm{F}$ & $\mathrm{H}$ & $\mathrm{G}$ & $\mathrm{N}$ & $\mathrm{S}$ & $\mathrm{R}$ & $\mathrm{R}$ & 4 & 0 \\
\hline T101 & I & A & II & II & Japan-D & A & $\mathrm{Y}$ & $\mathrm{R}$ & V & $\mathrm{N}$ & $\mathrm{S}$ & $\mathrm{S}$ & $\mathrm{R}$ & 4 & $0-1$ \\
\hline S12 & III & $\mathrm{B}(\mathrm{J})$ & I & II & Japan-O & A & $\mathrm{F}$ & $\mathrm{H}$ & $\mathrm{G}$ & $\mathrm{N}$ & $\mathrm{S}$ & $\mathrm{R}$ & $\mathrm{R}$ & 4 & 0 \\
\hline $\mathrm{FP}$ & II & $\mathrm{A}(\mathrm{P})$ & II & II & France-P & $\mathrm{S}$ & $\mathrm{Y}$ & $\mathrm{H}$ & $\mathrm{G}$ & $\mathrm{N}$ & $\mathrm{S}$ & $\mathrm{S}$ & $\mathrm{R}$ & 4 & 1 \\
\hline CH6 & I & $\mathrm{B}(\mathrm{C})$ & nt & I & China-H & A & $\mathrm{Y}$ & $\mathrm{H}$ & $\mathrm{G}$ & $\mathrm{N}$ & $\mathrm{S}$ & $\mathrm{S}$ & $\mathrm{R}$ & nt & nt \\
\hline CY1 & I & A & I & I & China-H & A & $\mathrm{C}$ & $\mathrm{H}$ & $\mathrm{G}$ & $\mathrm{N}$ & $\mathrm{S}$ & $\mathrm{S}$ & $\mathrm{S}$ & 4 & 1 \\
\hline $\mathrm{CH} 3$ & I & $\mathrm{B}(\mathrm{C})$ & I & I & China-H & $\mathrm{A}$ & $\mathrm{H}$ & $\mathrm{H}$ & $\mathrm{G}$ & $\mathrm{N}$ & $\mathrm{S}$ & $\mathrm{S}$ & $\mathrm{S}$ & 4 & 1 \\
\hline CX5 & I & $\mathrm{A}$ & I & III & China-X & A & $\mathrm{H}$ & $\mathrm{H}$ & $\mathrm{R}$ & $\mathrm{N}$ & $\mathrm{S}$ & $\mathrm{S}$ & $S$ & $3-4$ & $0-1$ \\
\hline CY3 & I & A & III & III & China-X & A & $\mathrm{Y}$ & $\mathrm{H}$ & $\mathrm{R}$ & $\mathrm{D}$ & $\mathrm{S}$ & $\mathrm{S}$ & $\mathrm{S}$ & nt & nt \\
\hline
\end{tabular}

a Minus signs (-) indicate the absence of RNA5; nt = not tested.

b Japan-T (in parenthesis) is included in China-H subgroup.

${ }^{\mathrm{c}}$ For foliar rub inoculation of Beta vulgaris subsp. maritima, virulence was estimated by the response of inoculated leaves; $\mathrm{S}=$ susceptible response and $\mathrm{R}=$ resistant.

${ }^{\mathrm{d}}$ For root vector inoculation of sugar beet cultivars, the symptom intensity was scored from 1 to 4 , with 1 being mild and 4 very severe; $0=$ no obvious symptoms. Monomidori (Mono) and Schwert (Schw) are susceptible and Rzl-resistant cultivars, respectively.

\section{Symptom} index

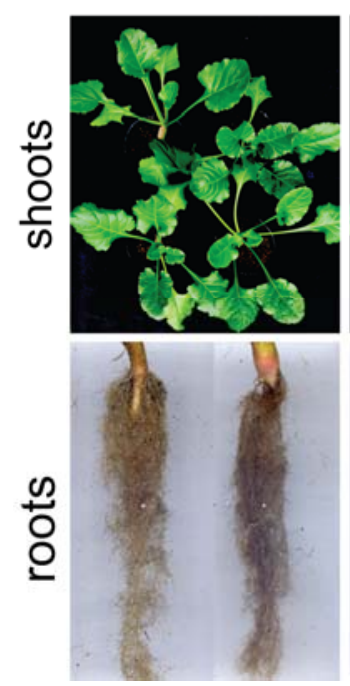

1
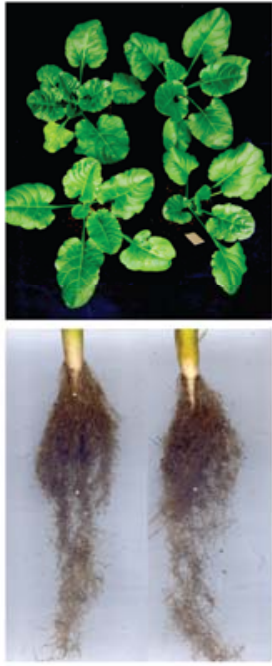

2
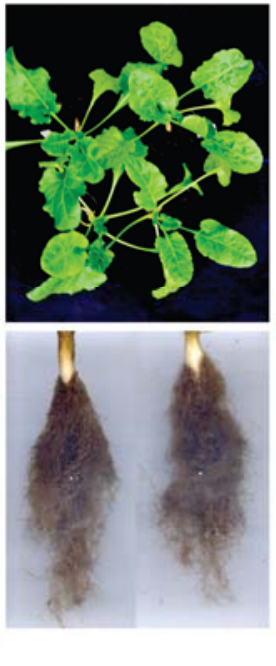

3
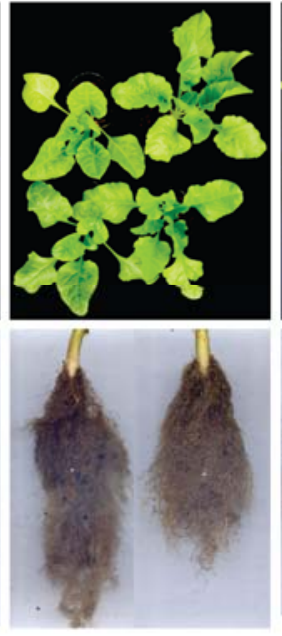

4
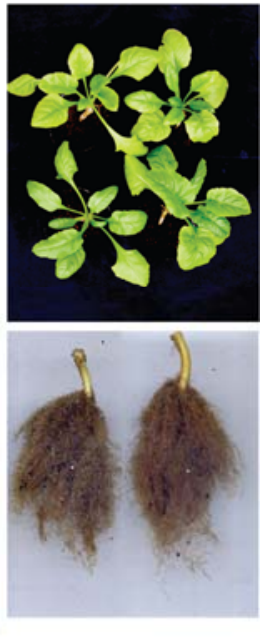

Fig. 2. Shoots and roots of sugar beet plants inoculated by Polymyxa betae carrying Beet necrotic yellow vein virus. Figures at top indicate the symptom index based on the degrees of stunting and yellowing of shoots and abnormal proliferation of rootlets (hair roots): $4=$ very severe, $3=$ severe, $2=$ moderate, $1=$ faint or mild, and $0=$ no symptoms. Those with mild symptoms (index 1 ) often also show faint yellowing of shoots or slight proliferation of rootlets late in infection. 
and GW) failed to induce any symptoms in roots and shoots, whereas four isolates (SLN1, IP7, IV1, and USTH) induced mild symptoms, and isolate SPC induced more prominent symptoms. Thus, from response differences of the Italy isolates (Table 3 ), amino acid changes from $\mathrm{F}$ or $\mathrm{Y}$ to $\mathrm{C}, \mathrm{H}, \mathrm{L}$, or $\mathrm{Q}$ at position 68 in p25 appeared to control symptoms in a resistant cultivar; and, furthermore, an amino acid change from $\mathrm{A}$ to $\mathrm{V}$ at position 67 appeared to intensify symptoms. Such BNYVV isolates can be called $R z l-\mathrm{RB}$ variants.

The virulence of RNA5-containing BNYVV isolates varied. Two isolates ( $\mathrm{SH} 1$ and $\mathrm{S} 12$ ) failed to induce any symptoms, whereas infection by five isolates (T101, FP, CY1, CH3, and CX5) induced faint or mild symptoms (Table 3). Thus, both p25 and RNA5 affect virulence in a Rz1-resistant cultivar; a laboratory isolate of FP that lacks RNA5 failed to induce any symptoms on the resistant cultivar (data not shown), indicating that, although the RNA5-p26 gene seems to increase pathogenicity and RB, it achieves this in a different fashion than the p25 gene (Heijbroek et al. 1999; Link et al. 2005; Pferdmenges et al. 2009; Tamada et al. 1996).

\section{Identification of $\mathbf{p 2 5}$ amino acids responsible for $\mathbf{R B}$.}

As described above, the amino acids at positions 67 and 68 of p25 affect RB. Some Italy isolates yield mixtures of amino acid residues at position 68 , indicating that they are mixed populations in fields, as previously reported by Acosta-Leal and associates (2008), who compared the frequency of infection by 25 variants in susceptible and resistant cultivars grown in the field. Therefore, we examined the frequency of p25 variants in roots of different sugar beet cultivars that had been inoculated with mixtures of BNYVV isolates containing p25 with different amino acid compositions. For mixed infections, three Japanese isolates and five Italy isolates were used as inoculum sources (Table 4). After three passages in susceptible and resistant sugar beet cultivars using vector inoculation, 20 cDNA clones were prepared from each root sample using reverse-transcription polymerase chain reaction (RT-PCR) (p25 55-72 forward and p25 334-354 reverse primers) and were sequenced.

The results show clear differences (Table 4). For Japanese isolates infecting the susceptible cultivar or the $R z l$-resistant cultivar (experiment 1), p25 variants with Y68 predominated over those with F68, although, in the susceptible cultivar, those with F68 appear to be frequent. Likewise, for mixtures of Italy isolates (experiments 2 and 3), in the Rzl-resistant cultivar, p25 variants with V67 and C68 were dominant and, in the case of p25 with A67, p25 variants with L68 and C68 were dominant; whereas, in the susceptible cultivar, although p25 variants with V67 and C68 were also most common, other p25 variants with A67 and F68, L68, or C68 appear to be frequent.

To ascertain whether p25 with V67 and C68 is responsible for stronger levels of RB ability, we made reassortment experiments using RNA3 transcripts from the two Italy isolates SLP2 and SPC (T3SLP2 with A67 and F68 and T3SPC with V67 and C68, respectively). Laboratory isolates SLP2-4 and SPC-4, lacking RNA3, were mixed with T3SPC and T3SLP2 transcripts, respectively. $P$. betae cultures carrying each of the reassortment mutants were inoculated onto roots of susceptible and resistant sugar beet cultivars. The results showed that, in the resistant cultivar, SLP2-4 containing T3SPC or SPC alone induced severe symptoms in roots and shoots, whereas SPC-4 containing T3SLP2 or SLP2 alone produced no symptoms (data not shown). This clearly indicates that a p25 with V67 and C68 is responsible for the strong RB, whereas a p25 with A67 and F68 is not RB, because there were no other differences in amino acid sequences between T3SPC and T3SLP2 (Table 2). Other evidence that increased virulence in resistant cultivars is associated with p25 containing V67 was provided previously (Acosta-Leal et al. 2008, 2010; Koenig et al. 2009; Pferdmenges et al. 2009).

\section{DISCUSSION}

The geographical origins and migration route of BNYVV.

In this study, we have analyzed the sequence variation in the coding region of four genes in each of 73 BNYVV isolates collected worldwide (Fig. 1). We find that the isolates fall into eight clusters that form four lineages.

Based on these analyses, we propose a hypothesis to explain the evolutionary history and route of spread of BNYVV (Fig. $3 \mathrm{~A}$ ). We propose the early divergence of the A and B lineages and further divergences to produce three A lineages. No B lineage isolates have an RNA5 genome component and, because RNA5 is not essential for BNYVV infectivity, it has also been subsequently lost from some A lineage population.

The three essential genes we have studied (those encoding the $C P, p 25$, and $p 31$ sequences) have produced variants, and combinations of these are found in the eight clusters or strains that are now evident and which are best distinguished by the p25 they encode (Fig. 3A). Italy strain isolates derived from the A-III type source were first found in Italy in the early 1950 s, and have spread in Europe, to the Middle East, and to the United States during approximately 30 years. Similarly,

Table 4. Sequence analyses of the p25 variants found in susceptible and resistant sugar beet cultivars after inoculation of Beet necrotic yellow vein virus (BNYVV) isolates containing mixed and different p25 sequences

\begin{tabular}{|c|c|c|c|c|c|c|c|}
\hline \multirow[b]{2}{*}{ Exp. } & \multirow[b]{2}{*}{ BNYVV source (mixed inoculum) ${ }^{\text {b }}$} & \multicolumn{4}{|c|}{ p25 position ${ }^{a}$} & \multicolumn{2}{|c|}{ Number of clones (\%) } \\
\hline & & 67 & 68 & 69 & 70 & Monomidori & Schwert \\
\hline \multirow[t]{3}{*}{1} & Japanese isolates $(\mathrm{O} 11, \mathrm{~S} 113$, and $\mathrm{T} 41)$ & A & $\mathbf{F}$ & $\mathbf{H}$ & $\mathbf{G}$ & $4(20)$ & $1(5)$ \\
\hline & & A & $\mathbf{Y}$ & $\mathbf{R}$ & $\mathbf{V}$ & $5(25)$ & $1(5)$ \\
\hline & & A & $\mathbf{Y}$ & $\mathbf{H}$ & $\mathbf{G}$ & $11(55)$ & $18(90)$ \\
\hline \multirow[t]{4}{*}{2} & Italy isolates (SLP2, SLN1, IP7, and USTH) & A & $\mathbf{F}$ & $\mathrm{H}$ & $\mathrm{G}$ & $7(35)$ & $0(0)$ \\
\hline & & A & $\mathbf{H}$ & $\mathrm{H}$ & G & $1(5)$ & $1(5)$ \\
\hline & & A & $\mathbf{L}$ & $\mathrm{H}$ & $\mathrm{G}$ & $5(25)$ & $13(65)$ \\
\hline & & A & $\mathbf{C}$ & $\mathrm{H}$ & $\mathrm{G}$ & $7(35)$ & $6(30)$ \\
\hline \multirow[t]{5}{*}{3} & Italy isolates (SLP2, SLN1, IP7, USTH, and SPC) & $\mathbf{A}$ & $\mathbf{F}$ & $\mathrm{H}$ & $\mathrm{G}$ & $3(15)$ & $0(0)$ \\
\hline & & $\mathbf{A}$ & $\mathbf{H}$ & $\mathrm{H}$ & $\mathrm{G}$ & $4(20)$ & $0(0)$ \\
\hline & & $\mathbf{A}$ & $\mathbf{L}$ & $\mathrm{H}$ & G & $0(0)$ & $0(0)$ \\
\hline & & $\mathbf{A}$ & $\mathbf{C}$ & $\mathrm{H}$ & $\mathrm{G}$ & $0(0)$ & $0(0)$ \\
\hline & & V & $\mathbf{C}$ & $\mathrm{H}$ & G & $13(65)$ & $20(100)$ \\
\hline
\end{tabular}

\footnotetext{
${ }^{a}$ Bold letters indicate p25 amino acid residues that differed among the inoculum isolates.

${ }^{\mathrm{b}}$ Plants of the susceptible cv. Monomidori and Rzl-resistant cv. Schwert were inoculated with mixtures using viruliferous Polymyxa betae. After three such passages, 20 cDNA clones were prepared from each sample of sugar beet roots and were sequenced.
} 
Germany strain isolates derived from the B type source were first found in limited areas of Germany and France in the early 1970s, and have then spread in Europe (Koenig et al. 2008). The Chinese isolate CX1, which is identical to the Germany strain, was found at Shiheji in Xingjiang province in 2000; however, CX1 may have been introduced from Europe. For four strains (France-P, Japan-D, Japan-O, and China-B) derived from the A-II type source, the France-P strain was detected in limited areas of Europe, Kazakhstan (Koenig and Lennefors 2000), and, recently in the United Kingdom (Ward et al. 2007) and Iran (Mehrvar et al. 2009) but not in China or Japan, whereas the Japan-D and Japan-O strains were found in Japan and the China-B strain was found in China ( $\mathrm{Li}$ et al. 2008) and, recently, in Germany (Koenig et al. 2008).

In contrast to isolates derived from the A-II, A-III, and B types described above, many isolates of China- $\mathrm{H}$ and China- $\mathrm{X}$ strains and some isolates of strain Japan-O have more complex genomes (Fig. 3A). For example, some China-H isolates seem to have the A-I type $C P$ but some have B lineage $\mathrm{CP}$. Likewise,
China-X isolates have different $p 31$ genes and different isolates of the Japan-O strain possess different $C P$ and $p 31$ genes. Thus, these reassortant isolates, which were excluded in the concatenate sequence analysis (Fig. 1A), result from mixed infections of different source isolates.

It is noteworthy that the greatest diversity of BNYVV genomes was found in Chinese and Japanese isolates in East Asia. This suggests that the ancestral BNYVV may have emerged from native hosts in East (or Central) Asia, not in the Middle East or Europe. The four original lineages and their derived progeny strains (Fig. 3A) probably existed in native hosts in East Asia long before sugar beet cultivation began. The sugar beet crop was developed in Europe in the early part of the 19th century and its cultivation spread to other temperate regions in the 20th century (Winner 1993). In Japan, sugar beet was first grown in Hokkaido in 1880 and regular cultivation started around 1920 (Winner 1993) but no outbreaks of BNYVV were reported until the middle 1960s (Kanzawa and Ui 1972; Tamada and Baba 1973). In China, sugar beet was

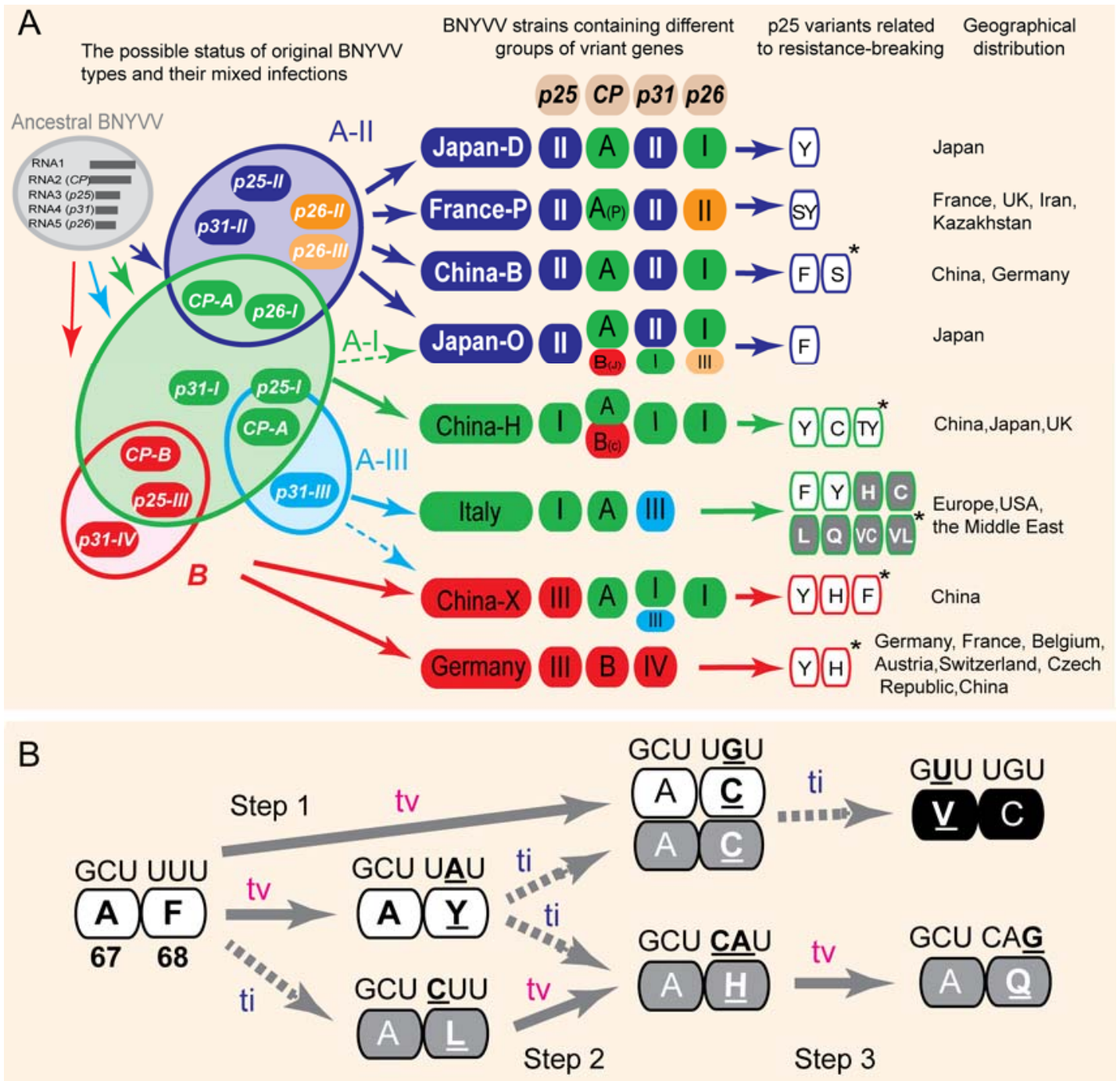

Fig. 3. Cartoon showing the likely evolutionary history of Beet necrotic yellow vein virus (BNYVV). A, Evolutionary steps and geographical distribution of BNYVV strains (and p25 variants) derived from four original variant BNYVV populations and their mixed infections. The p25 variants show different resistance-breaking (RB) ability. Oval contours (at left) indicate the four original BNYVV populations, and their mixed infections are indicated by the overlaps. Each type of the four genes is indicated by a different contrasting density. Solid arrows indicate major lineages, and dotted arrows indicate the lesser reassortant lineages. Names of p25 variants are based on the p25 amino acid residues at positions 67 and 68, which were associated with RB. Gray boxes indicate $R z 1$-RB types, and white boxes indicate non-RB types. The asterisks indicate $\mathrm{p} 25$ variants for which RB ability was not determined. B, Mutational pathways to $R z 1-\mathrm{RB}$ of the $\mathrm{p} 25$ amino acids at positions 67 and 68 . The gray and dotted arrows indicate transversion (tv) and transition (ti) substitutions, respectively. The white boxes indicate amino acids associated with non-RB status. The gray and black boxes indicate amino acids associated with the mutant virulent and severely virulent types, respectively. The nucleotides and amino acid residues that were substituted are underlined. 
introduced and first grown as a new field crop in the 1960s. BNYVV was first found at Bautou in Nei Menggu in 1978 (Gao et al. 1983) and subsequently spread to many areas along the Hwang river (Nei Menggu, Ningxia Huizu, and Gansu provinces). BNYVV was found in more distant provinces (Xingjian and Heilongjiang) in the 1980s. BNYVV is spread primarily through the movement of soils containing viruliferous $P$. betae resting spores (e.g., by global or local movement along with plant materials and other sources by humans, and by natural spread of the desiccation-resistant spores by wind or water or on animals such as migratory birds) (Asher 1993; Tamada 1999). Indeed, it is possible that the emergence of BNYVV from native hosts and soils into sugar beet crops is quite recent; perhaps only in the last half century. Each original population of BNYVV described above might have passed through successive bottleneck transmission in different hosts at different places during different periods. $P$. betae can persist in infested soil for many years; therefore, once a field becomes contaminated with BNYVV, it remains permanently infested (Asher 1993). In addition, viruliferous $P$. betae can multiply very rapidly in sugar beet crops; 10,000 -fold increases in inoculum are reported after a single growing season (Tuitert and Hofmeester 1992). This is one reason why BNYVV has spread so rapidly.

Both BNYVV and its vector $P$. betae seem to have limited host ranges (Barr and Asher 1992; Hugo et al. 1996; Tamada and Baba 1973) but we suspect that wild beet or related species may not be their native hosts. In this respect, we note that, in the United States, BNYVV was isolated first from soil samples collected from beneath cherry trees in a district in the Washington State, where sugar beet had never been cultivated (Al Musa and Mink 1981). Further work is needed to search for the natural hosts of BNYVV and P. betae.

\section{The genetic diversity and structure of BNYVV population.}

We showed that the mean nucleotide diversity of all BNYVV isolates for the four sequenced genes was relatively low (0.016 to 0.025) and that of the within-group of BNYVV isolates was even lower (0.002 to 0.018), suggesting that BNYVV populations are genetically very stable or have diverged recently, and that the mutation rate seemed to be similar for the four genes but mutation frequency differed between isolate group (i.e., locality).

Despite such a low nucleotide diversity among BNYVV isolates, a most intriguing conclusion in the present study is that the selection pressures varied greatly depending on the gene and the geographical source of isolate. For all isolates, the value of $d_{N S} / d_{S}$ for $C P$ was 0.089 , similar to that reported for the $\mathrm{CP}$ of many other plant RNA viruses, indicating that they are strongly conserved (Chare and Holmes 2004; Garcia-Arenal et al. 2001). In contrast, the values of $d_{N S} / d_{S}$ for the other genes (0.778 to 0.327$)$ are several times greater than that for $C P$. Particularly noteworthy is that the $d_{N S} / d_{S}$ values for $p 25$ differed greatly in different $p 25$ groups (1.167 to 0.433$)$. There were similar but lesser differences for the other genes. Together, these results suggest that, for each gene, different degrees of selection may operate in different geographical areas.

If we consider the nucleotide genome diversity of the Italy strain, the relationships between isolates can be explored in more depth. Presumably, this strain was introduced into Italy some years before the discovery of rhizomania in the 1950s, and may have come from a single genotype, with the resulting progeny variants having spread worldwide during the subsequent 30 years. The nucleotide diversity values for $p 25$ and p31 were almost similar (0.005 and 0.004 , respectively), although that for $C P$ was slightly lower (0.002) (Table 1). However, the values of $d_{N S} / d_{S}$ differed greatly with BNYVV genes $p 25$ (1.500), p31 (0.500), and $C P$ (0.333). Thus, the $p 25$ gene was subject to very strong positive selection. Indeed, the values for each gene of the Italy strain were higher than those for other groups (Table 1). This suggests that the existence of the highest selective pressure on p25 may influence selection pressure on the other genes. Alternatively, strong selection pressure may be imposed in parallel on all BNYVV proteins. As described below, we argue that the existence of such strong positive selection pressure on the $p 25$ gene is associated with cultivation of resistant cultivars.

\section{The emergence of RB variants and its mechanism.}

Our inoculation tests showed that many isolates of the Italy strain were able to overcome $R z l$ resistance at various levels, whereas other Japanese, France-P (without RNA5), and Germany isolates could not overcome $R z l$-mediated resistance. Some RNA5-containing isolates caused symptoms in $R z 1$-resistant sugar beet cultivars. Thus, the RNA5-p26 gene and the p25 gene may be involved in RB in different ways (T. Tamada, unpublished data). The present studies, and other reported previously (Chiba et al. 2008), show that p25 amino acid residues at position 68 play a major role in the resistance response, although other positions in p25 may influence RB. Notably, the amino acid change $(\mathrm{A} \rightarrow \mathrm{V})$ at position 67 seemed to be associated with the Rzl-RB (Acosta-Leal et al. 2008, 2010; Koenig et al. 2009; Pferdmenges et al. 2009).

To differentiate BNYVV isolates containing p25 variants in relation to $\mathrm{RB}$, we tentatively named the variant types such as F, Y, C, H, L, Q, and VC (Fig. 3A) at position 68 or both positions 67 and 68. In the United States, BNYVV variants with V67 and L68 (VL-variant) were prevalent (Liu and Lewellen 2007) and associated with RB (Acosta-Leal and Rush 2007; Acosta-Leal et al. 2008, 2010). Overall, we suggest that the relative $\mathrm{RB}$ ability for these $\mathrm{p} 25$ variants is $\mathrm{F}<\mathrm{Y}<\mathrm{C}=\mathrm{L}=\mathrm{H}$ $<\mathrm{Q}<\mathrm{VC}$. However, the $\mathrm{C}$ and $\mathrm{H}$ variants in the Italy strain were $\mathrm{RB}$ but $\mathrm{C}$ and $\mathrm{H}$ variants in Chinese isolates seemed to be non-RB (Table 3; data not shown), and p25 amino acid differences between Chinese and Italy isolates (Table 2) suggest that other positions in $\mathrm{p} 25$ or a gene or genes other than $p 25$ may have an influence on RB. Other p25 variants with S (China-B) (Li et al. 2008), TY (French-P) (Ward et al. 2007), or H (Germany) (Koenig et al. 2008) (Fig. 3A) have been reported but it is not clear whether these isolates are RB.

Based on the p25 variants of the Italy strain, we suggested mutational pathways to RB at two positions, 67 and 68, in p25 (Fig. 3B). At the first step, the ancestral amino acid $\mathrm{F}$ at position 68 changed to $\mathrm{Y}$ and $\mathrm{C}$ by a transversion substitution ( $\mathrm{U} \rightarrow \mathrm{A}$ and $\mathrm{U} \rightarrow \mathrm{G}$, respectively). The reverse also occurs, and may explain how $\mathrm{Y}$ or $\mathrm{C}$ was frequently present in p25 of Chinese and Japanese isolates (Table 2). An alternative first step is the change from $\mathrm{F}$ to $\mathrm{L}$ by a transition substitution $(\mathrm{U} \rightarrow \mathrm{C})$. At the second step, although $\mathrm{Y}$ can change $\mathrm{C}$ or $\mathrm{H}$ by a transition $(A \rightarrow G$ or $U \rightarrow C$, respectively), the transversion from $L$ to $H$ $(\mathrm{U} \rightarrow \mathrm{A})$ is probably more frequent. At the second step (or the third step), the wild-type p25 amino acid A at position 67 is also changed to $\mathrm{V}$ by a transition substitution $(\mathrm{C} \rightarrow \mathrm{U})$. At the third step, amino acid change to $\mathrm{Q}$ from $\mathrm{H}$ occurs by a transversion $(\mathrm{U} \rightarrow \mathrm{G})$ but this was found in only one isolate. It is interesting to see that the order of these mutational changes parallels the degree of RB ability described above.

Undoubtedly, the emergence of RB virus variants has been fostered by the introduction of resistant cultivars. Indeed, since the early 1970s, when BNYVV became a threat to sugar beet production in Europe, Rizor-mediated resistant sugar beet cultivars were first grown in infested fields in the 1980s (Asher 1993). In contrast, few or no resistant cultivars such as Rizor were grown in Japan until the early 1990s (years sampled in 
this study), and probably also in China, although sugar beet cultivars with moderate levels of resistance had been grown in Japan earlier. It seems unlikely that the variations in $p 25$ sequences found in Japanese and Chinese isolates were directly involved in RB. Hence, they may have been associated with other host-imposed factors, leading to positive selection pressure on the $p 25$ gene in the past.

\section{Conclusions.}

We proposed that the evolutionary history of BNYVV while spreading worldwide is as follows: i) several subpopulations have diverged from at least four original types of populations and their mixed infections in native hosts in East Asia long before sugar beet was cultivated; ii) more recently (perhaps for the last half century), BNYVV sources with diverse origins from native hosts have introduced infection to cultivated sugar beet plants in different areas during different periods and have spreading extensively; iii) in areas growing resistant cultivars, strong selection pressure has been imposed on the $p 25$ gene and, as a consequence, RB variants that have single aminoacid changes in p25 have been fostered; and iv) these newly generated virus variants are more advantageous in resistant sugar beet cultivars than previous virus isolates although these variants probably coexist as quasispecies in the field (AcostaLeal et al. 2008). This evolutionary trajectory is comparable with recent spread and evolution of Rice yellow mottle virus (RYMV) in Africa, although RYMV has approximately 10 times higher values of the nucleotide diversity than BNYVV but is inefficient at RB (Fargette et al. 2004; Pinel-Galzi et al. 2007). It can be compared with mutation to drug-mediated resistance in animal viruses such as Human immunodeficiency virus (Nkengasong et al. 2004).

\section{MATERIALS AND METHODS}

\section{Virus isolates.}

BNYVV isolates used in this study were derived from soil samples collected from rhizomania-inducing fields worldwide. Japanese isolates were sampled from different areas throughout Hokkaido in 1991 to 1995 . For Chinese isolates, soil samples were collected from fields in Nei Menggu, Ninxia Huizu, Gansu, Xinjiang, and Heilongjiang provinces in 1992 to 2006. For European and U.S. isolates, soil samples were generously supplied by M. Fattori (France, Germany, and Italy), R. Resca (Italy), V. Horvath (Hungary), V. Subikova (Slovakia), E. de Bruyne (France, Germany, and Spain), M. Arli-Sokmen (Turkey), and C. M. Rush (United States) in 1995 to 2000. All isolates were obtained from soils using bait plants (susceptible sugar beet cv. Monomidori). At least three seedlings were grown in special test tubes containing a mixture of each soil sample and quartz sand. After 1 month in a growth cabinet (23 to $25^{\circ} \mathrm{C}$ with a cycle of $16 \mathrm{~h}$ of light and $8 \mathrm{~h}$ of darkness), sap or total nucleic acid extracted by the sodium dodecyl sulfatephenol method from rootlets was inoculated to leaves of $T$. expansa, in which each virus isolate was propagated and used for sequencing and as inoculum. In this process, some BNYVV isolates were found to contain other soilborne viruses such as Beet soilborne virus or Tobacco necrosis virus, but these contaminants were eliminated from inoculum sources.

\section{RT-PCR, cloning, and sequencing.}

Extraction of total RNA from infected leaves or roots, cDNA synthesis, and PCR amplification were conducted as described previously (Chiba et al. 2008; Miyanishi et al. 1999). Nucleotide sequences of all PCR primers used in this study are listed in Supplementary Table S4. The primers RT-3F and RT-3R for RNA3 (p25); RT-4F and RT-4R for RNA4 (p31); RT-5F and
RT-5R for RNA5 (p26); and 2C, RT-CP-F, and RT-CP-R for RNA2 (CP) were used. PCR products were ligated into a pGEM-T vector (Promega Corp., Madison, WI, U.S.A.) and transformed into Escherichia coli DH5 $\alpha$. The nucleotide sequences of selected clones were determined with an ABI3100 DNA sequencer (Applied Biosystems, Foster City, CA, U.S.A.). For each gene of each isolate, at least three independent clones were sequenced, unless otherwise stated. Nucleotide sequences of some isolates and sequence differences among clones were also resolved by direct sequencing of RT-PCR products. For this purpose, the primers used were R2-1 and R2-2 for CP, R31 and R3-2 for p25, R4-1 and R4-2 for p31, and R5-1 and R52 for $\mathrm{p} 26$. For some experiments, part of $p 25$ was amplified by the primers p25 55-72 forward and p25 334-354 reverse and its sequence was determined.

\section{Sequence analysis.}

Nucleotide sequences of the four BNYVV genes $(C P, p 25$, $p 31$, and $p 26$ ) were aligned with those of orthologs from BSBMV by using MAFFT version 6 under the default parameters (Katoh and Toh 2008). Alignments were edited by using MEGA4 version 4.02 software (Tamura et al. 2007). ML tree inferences were carried out with PhyML 3.0 (Dereeper et al. 2008), employing the general time reversible substitution model, gamma parameter estimated, number of substitution categories $=4$, initial tree $\mathrm{BIONJ}$, and type of tree improvement NNI. The ML bootstrap support was calculated from 100 bootstrap replicates. The obtained tree was visualized using FigTree v1.3.1 software. The phylogenetic trees for the three genes $(C P, p 25$, and $p 31)$ were found to have different topology; therefore, we checked whether some BNYVV isolates are recombinants or the genes had reassorted. The three genes for each BNYVV isolate were jointed to form a single concatenated sequence. The aligned concatenated sequences were edited and then examined using the RDP3 program (Martin 2009) to check for phylogenetic anomalies. Anomalous sequences were removed and the phylogenies of the remaining gene sequences were determined.

Nucleotide distances and nucleotide diversity (mean nucleotide distance between two randomly selected sequence variants) were estimated by the maximum-composite-likelihood method with MEGA version 4.02 (Tamura et al. 2007). Pairwise synonymous substitutions per synonymous site $\left(d_{S}\right)$ and nonsynonymous substitutions per nonsynonymous site $\left(d_{N S}\right)$ were also calculated according to the PBL method based on Kimura's two-parameter model (Li 1993; Pamilo and Bianchi 1993). Standard deviations were calculated by the bootstrap method, with 500 repeats.

\section{Virulence tests.}

For virulence tests by rub inoculation, BNYVV isolates were inoculated to leaves of three differential lines of wild beet $B$. vulgaris subsp. maritima MR0, MR1, and MR2 (Chiba et al. 2008; Tamada 2007). Susceptible and resistant responses were assessed based on the reactions of the inoculated leaves. For virulence tests by vector inoculation, $P$. betae cultures carrying each virus isolate were prepared as described previously (Rahim et al. 2007). The $P$. betae cultures were inoculated to roots of susceptible sugar beet cv. Monomidori and resistant cv. Schwert (both Japanese breeding lines). Schwert ( $R z 1 r z l)$ has a single resistance gene, $R z 1$, and showed a higher level of resistance than cv. Rizor but a lower level of resistance than other resistant cultivars carrying $R z 1$ and $R z 2$ or minor genes (T. Tamada, unpublished data). Also, this cultivar had individually no or little variation in response to BNYVV, whereas some individual variations were found in other $R z l$-mediated resistant cultivars or lines tested. Inoculated seedlings were 
grown in a growth cabinet for 3 to 4 weeks and then transplanted and grown in the greenhouse for 2 to 3 months. Symptom severity (index 0 to 4 ) in roots and shoots was scored based on 8 to 10 plants per treatment (Fig. 2). Virus was detected in tissues as described previously (Andika et al. 2005).

To examine the relative prevalence of $p 25$ variants in mixed infections of BNYVV isolates in roots of different sugar beet cultivars, equal volumes of each inoculum source that contained dried rootlets containing resting spores of viruliferous $P$. betae were mixed and inoculated to roots of susceptible and resistant sugar beet cultivars. After 6 weeks in the growth cabinet, dried rootlet samples from each of the inoculated plants were again inoculated to the respective sugar beet cultivars.

To produce reassortant mutants, RNA3 was exchanged between wild-type isolates SLP2 and SPC, which differ in virulence. The full-length RNA3 cDNA clones pT3SLP2 and pT3SPC of isolates SLP2 and SPC, respectively, were prepared as described previously (Chiba et al. 2008). The laboratory isolates SLP2-4 and SPC-4, both of which lack RNA3, were obtained from SLP2 and SPC by single-lesion transfers on $T$. expansa leaves. For the infection tests, a freshly prepared transcript from each cDNA plasmid (T3SLP2 or T3SPC) was mixed with viral RNA partially purified from SLP2-4- (or SPC-4)-inoculated T. expansa leaves. Each mixture was propagated in $T$. expansa leaves, from which the respective viruscarrying $P$. betae cultures were prepared as described. These cultures were inoculated to roots of the different sugar beet cultivars. Identity of the progeny viruses from vector-inoculated roots of sugar beet plants was confirmed by sequencing RT-PCR products as described above.

\section{ACKNOWLEDGMENTS}

We thank M. Fattori, R. Resca, J. Horvath, V. Subikova, M. Arli-Sokmen, E. De Bruyne, and C. M. Rush for kindly providing BNYVV samples; T. Kusume, Y. Liu, L. Yang, and B. Xiang for help with sampling of Japanese and Chinese isolates; K. Maruyama and A. Kajitani for help with sequence analyses; A. J. Gibbs for great help for phylogenetic analyses; B. D. Harrison, A. J. Gibbs, and N. Suzuki for helpful comments on the text. This work was supported in part by a Grant-in-Aid for Scientific Research [KAKENHI] from the Japanese Ministry of Education, Culture, Sport, Science and Technology, by the Hokkaido Sugar Beet Association, and by Yomogi Inc.

\section{LITERATURE CITED}

Acosta-Leal, R., and Rush, C. M. 2007. Mutations associated with resistance-breaking isolates of Beet necrotic yellow vein virus and their allelic discrimination using TaqMan technology. Phytopathology 97:325330.

Acosta-Leal, R., Fawley, M. W., and Rush, C. M. 2008. Changes in the intra isolate genetic structure of Beet necrotic yellow vein virus populations associated with plant resistance breakdown. Virology 376:60-68.

Acosta-Leal, R., Bryan, B. K., Smith, J. T., and Rush, C. M. 2010. Breakdown of host resistance by independent evolutionary lineages of Beet necrotic yellow vein virus involves a parallel $\mathrm{C} / \mathrm{U}$ mutation in its p25 gene. Phytopathology 100:127-133.

Al Musa, A. M., and Mink, G. I. 1981. Beet necrotic yellow vein virus in North-America. Phytopathology 71:773-776.

Andika, I. B., Kondo, H., and Tamada, T. 2005. Evidence that RNA silencing-mediated resistance to Beet necrotic yellow vein virus is less effective in roots than in leaves. Mol. Plant-Microbe Interact. 18:194-204.

Asher, M. J. C. 1993. Rhizomania. Pages 311-346 in: The Sugar Beet Crop: Science into Practice. D. A. Cooke and R. K. Scott, eds. Chapman \& Hall, London.

Barr, K. J., and Asher, M. J. C. 1992. The host range of Polymyxa betae in Britain. Plant Pathol. 41:64-88.

Biancardi, E., Lewellen, R. T., de Biaggi, M., Erichsen, A. W., and Stevanato, P. 2002. The origin of rhizomania resistance in sugar beet. Euphytica 127:383-397.

Canova, A 1959. Appunti di pathologia sella barbabietola. Inf. Fitpathol. 9:390-396.

Chare, E. R., and Holmes, E. C. 2004. Selection pressures in the capsid genes of RNA plant viruses reflect mode of transmission. J. Gen. Virol. 85:3149-3157.

Chiba, S., Miyanishi, M., Andika, I. B., Kondo, H., and Tamada, T. 2008 Identification of amino acids of the beet necrotic yellow vein virus p25 protein required for induction of the resistance response in leaves of Beta vulgaris plants. J. Gen. Virol. 89:1314-1323.

Dereeper, A., Guignon, V., Blanc, G., Audic, S., Buffet, S., Chevenet, F., Dufayard, J. F., Guindon, S., Lefort, V., Lescot, M., Claverie, J. M., and Gascuel, O. 2008. Phylogeny.fr: Robust phylogenetic analysis for the non-specialist. Nucleic Acids Res. 36:465-469.

Fargette, D., Pinel, A., Abubakar, Z., Traorè, O., Brugidou, C., Fatogoma, S., Hèbrard, E., Choisy, M., Sèrè, Y., Fauquet, C., and Konatè, G. 2004 Inferring the evolutionary history of Rice yellow mottle virus from genomic, phylogenetic, and phylogeographic studies. J Virol. 78:32523261 .

Gao, J. L., Deng, F., Zhai, H. Q., Ling, X. S., and Liu, Y. 1983. The occurrence of sugar beet rhizomania caused by beet necrotic yellow vein virus in China. Acta Phytopathol. Sin. 13:1-4.

Garcia-Arenal, F., Fraile, A., and Malpica, J. M. 2001. Variability and genetic structure of plant virus populations. Annu. Rev. Phytopathol. 39:157-186.

Grimmer, M. K., Trybush, S., Hanley, S., Francis, S. A., Karp, A., and Asher, M. J. C. 2007. An anchored linkage map for sugar beet based on AFLP, SNP and RAPD markers and QTL mapping of a new source of resistance to Beet necrotic yellow vein virus. Theor. Appl. Genet. 114:1151-1160.

Harrison, B. D. 2002. Virus variation in relation to resistance-breaking in plants. Euphytica 124:181-192.

Heijbroek, W., Musters, P. M. S., and Schoone, A. H. L. 1999. Variation in pathogenicity and multiplication of beet necrotic yellow vein virus (BNYVV) in relation to resistance of sugar-beet cultivars. Eur. J. Plant Pathol. 105:397-405.

Hugo, S. A., Henry, C. M., and Harju, V. 1996. The role of alternative host of Polymyxa betae in transmission of beet necrotic yellow vein virus (BNYVV) in England. Plant Pathol. 45:662-666.

Kanzawa, K., and Ui, T. 1972. A note on rhizomania of sugar beet in Japan. Ann. Phytopathol. Soc. Jpn. 38:434-435.

Katoh, K., and Toh, H. 2008. Recent developments in the MAFFT multiple sequence alignment program. Brief. Bioinf. 9:286-298.

Kiguchi, T., Saito, M., and Tamada, T. 1996. Nucleotide sequence analysis of RNA-5 of five isolates of beet necrotic yellow vein virus and the identity of a deletion mutant. J. Gen. Virol. 77:575-580.

Koenig, R., and Lennefors, B.-L. 2000. Molecular analyses of European A, B and P type sources of beet necrotic yellow vein virus and detection of the rare P type in Kazakhstan. Arch. Virol. 145:1561-1570.

Koenig, R., Haeberle, A. M., and Commandeur, U. 1997. Detection and characterization of a distinct type of beet necrotic yellow vein virus RNA5 in a sugarbeet growing area in Europe. Arch. Virol. 142:14991504.

Koenig, R., Kastirr, U., Holtschulte, B., Deml, G., and Varrelmann, M. 2008. Distribution of various types and P25 subtypes of Beet necrotic yellow vein virus in Germany and other European countries. Arch. Virol. 153:2139-2144.

Koenig, R., Loss, S., Specht, J., Varrelmann, M., Luddeche, P., and Deml, G. 2009. A single U/C nucleotide substitution changing alanine to valine in the Beet necrotic yellow vein virus P25 protein promotes increased virus accumulation in roots of mechanically inoculated, partially resistant sugar beet seedlings. J. Gen. Virol. 90:759-763.

Kruse, M., Koenig, R., Hoffmann, A., Kaufmann, A., Commandeur, U., Solovyev, A. G., Savenkov, I., and Burgermeister, W. 1994. Restriction fragment length polymorphism analysis of reverse transcription-PCR products reveals the existence of two major strain groups of beet necrotic yellow vein virus. J. Gen. Virol. 75:1835-1842.

Lewellen, R. T., Skoyen, I. O., and Erichsen. A. W. 1987. Breeding sugarbeet for resistance to rhizomania: Evaluation of host-plant reactions and selection for and inheritance of resistance. Pages 139-156 in: Proc. Winter Congr. Symp. Int. Inst. Sugar Beet Res. (IIBR), 50th. Brussels.

Li, M., Liu, T., Wang, B., Han, C. G., Li, D. W., and Yu, J. L. 2008. Phylogenetic analysis of Beet necrotic yellow vein virus isolates from China. Virus Genes 36:429-432.

Li, W. H. 1993. Unbiased estimation of the rates of synonymous and nonsynonymous substitution. J. Mol. Evol. 36:96-99.

Link, D., Schmidlin, L., Schiremer, A., Klein, E., Erhardt, M., Geldreich, A., Lemaire, O., and Gilmer, D. 2005. Functional characterization of the Beet necrotic yellow vein virus RNA-5-encoded p26 protein: Evidence for structural pathogenicity determinants. J. Gen. Virol. 86:21152125.

Liu, H.-Y., and Lewellen, R. T. 2007. Distribution and molecular characterization of resistance-breaking isolates of Beet necrotic yellow vein 
virus in the United States. Plant Dis. 91:847-851.

Liu, H.-Y., Sears, J. L., and Lewellen, R. T. 2005. Occurrence of resistance-breaking Beet necrotic yellow vein virus of sugar beet. Plant Dis. 89:464-468

Martin, D. P. 2009. Recombination detection and analysis using RDP3. Methods Mol. Biol. 537:185-205.

McGrann, G. R. D., Grimmer, M. K., Mutasa-Gottgens, E. S., and Stevens, M. 2009. Progress towards the understanding and control of sugar beet rhizomania disease. Mol. Plant Pathol. 10:129-141.

Mehrvar, M., Valizadeh, J., Koenig, R., and Bragard, C. G. 2009. Iranian beet necrotic yellow vein virus (BNYVV): Pronounced diversity of the p25 coding region in A-type BNYVV and identification of P-type BNYVV lacking a fifth RNA species. Arch. Virol.154:501-506.

Miyanishi, M., Kusume, T., Saito, M., and Tamada, T. 1999. Evidence for three groups of sequence variants of beet necrotic yellow vein virus RNA 5. Arch. Virol. 144:879-892.

Nkengasong, J. K., Adje-Toure, C., and Weidle, P. J. 2004. HIV antiretroviral drug resistance in Africa. AIDS Rev. 6:4-12.

Ohshima, K., Yamaguchi, Y., Hirota, R., Hamamoto, T., Tomimura, K., Tan, Z. Y., Sano, T., Azuhata, F., Walsh, J.A., Fletcher, J., Chen, J. S., Gera, A., and Gibbs, A. 2002. Molecular evolution of Turnip mosaic virus: Evidence of host adaptation, genetic recombination and geographical spread. J. Gen. Virol. 83:1511-1521.

Pamilo, P., and Bianchi, N. O. 1993. Evolution of the Zfx and Zfy genesrates and interdependence between the genes. Mol. Biol. Evol. 10:271281.

Pferdmenges, F., Korf, H., and Varrelmann, M. 2009. Identification of rhizomania-infected soil in Europe able to overcome $R z 1$ resistance in sugar beet and comparison with other resistance-breaking soils from different geographic origins. Eur. J. Plant Pathol.124:31-43.

Pinel-Galzi, A., Rakotomalala, M., Sangu, E., Sorho, F., Kanyeka, Z., Traore, O., Sereme, D., Poulicard, N., Rabenantoandro, Y., Sere, Y., Konate, G, Ghesquiere, A., Hebrard, E., and Fargette, D. 2007. Theme and variations in the evolutionary pathways to virulence of an RNA plant virus species. PLoS Pathog. 3:e180.

Rahim, M. D., Andika, I. B., Han, C., Kondo, H., and Tamada, T. 2007. RNA4-encoded p31 of beet necrotic yellow vein virus is involved in efficient vector transmission, symptom severity and silencing suppression in roots. J. Gen. Virol. 88:1611-1619.

Richards, K. E., and Tamada, T. 1992. Mapping functions on the multipartite genome of beet necrotic yellow vein virus. Annu. Rev. Phytopathol. 30:291-313

Rush, C. M. 2003. Ecology and epidemiology of Benyviruses and plasmodiophorid vectors. Annu. Rev. Phytopathol. 41:567-592.

Saito, M., Kiguchi, T., Kusume, T., and Tamada, T. 1996. Complete nucleotide sequence of the Japanese isolate $S$ of beet necrotic yellow vein virus RNA and comparison with European isolates. Arch. Virol. 141:2163-2175

Schirmer, A., Link, D., Cognat, V., Moury, B., Beuve, M., Meunier, A., Bragard, C., Gilmer, D., and Lemaire, O. 2005. Phylogenetic analysis of isolates of Beet necrotic yellow vein virus collected worldwide. J. Gen. Virol. 86:2897-2911.

Scholten, O. E., and Lange, W. 2000. Breeding for resistance to rhizomania in sugar beet: A review. Euphytica 112:219-231.

Schwartz, R. S., and Mueller, R. L. 2010. Branch length estimation and divergence dating: Estimates of error in Bayesian and maximum likelihood frameworks. BMC Evol. Biol. 10:5.

Tamada, T. 1999. Benyviruses. Pages 154-160 in: Encyclopedia of Virology, 2nd ed. R. G. Webster and A. Granoff, eds. Academic Press, London.

Tamada, T. 2007. Susceptibility and resistance of Beta vulgaris subsp. maritima to foliar rub-inoculation with Beet necrotic yellow vein virus. J. Gen. Plant Pathol. 73:76-80.

Tamada, T., and Baba, T. 1973. Beet necrotic yellow vein virus from rhizomania affected sugar beet in Japan. Ann. Phytopathol. Soc. Jpn. 39:325332.

Tamada, T., Shirako, Y., Abe, H., Saito, M., Kigushi, T., and Harada, T. 1989. Production and pathogenicity of isolates of beet necrotic yellow vein virus with different numbers of RNA components. J. Gen. Virol. 70:3399-3409.

Tamada, T., Kusume, T., Uchino, H., Kiguchi, T., and Saito, M. 1996. Evidence that beet necrotic yellow vein virus RNA-5 is involved in symptom development of sugar beet roots. Pages 49-52 in: Proc. Symp. Int Working Group on Plant Viruses with Fungal Vectors, 3rd. J. L. Sherwood and C. M. Rush, eds. American Society of Sugar Beet Technologists, Denver.

Tamada, T., Uchino, H., Kusume, T., and Saito, M. 1999. RNA 3 deletion mutants of beet necrotic yellow vein virus do not cause rhizomania disease in sugar beets. Phytopathology 89:1000-1006.

Tamura, K., Dudley, J., Nei, M., and Kumar, S. 2007. MEGA4: Molecular Evolutionary Genetics Analysis (MEGA) software version 4.0. Mol. Biol. Evol. 24:1596-1599.

Tuitert, G., and Hofmeester, Y. 1992. Epidemiology of beet necrotic yellow vein virus in sugar beet at different initial inoculum levels in the presence or absence of irrigation; dynamics of inoculum. Neth. J. Plant Pathol. 98:343-360.

Ward, L., Koenig, R., Budge, G., Garrido, C., McGrath, C., Stubbley, H., and Boonham, N. 2007. Occurrence of two different types of RNA5 containing beet necrotic yellow vein virus in the UK. Arch. Virol. 152:59-73.

Winner, C. 1993. History of the crop. Pages1-35 in The Sugar Beet Crop: Science into Practice. D. A. Cooke and R. K. Scott, eds. Chapman \& Hall, London.

\section{AUTHOR-RECOMMENDED INTERNET RESOURCES}

FigTree database: tree.bio.ed.ac.uk/software/figtree

MAFFT multiple alignment program for amino acid or nucleotide sequences: mafft.cbrc.jp/alignment/server/phylogeny.html

PhyML website: www.phylogeny.fr 